\title{
Comparative Study of Community Participation after Joining Self Help Group members in Manakondur and Karimnagar
}

\author{
Dr. K. Srinivas ${ }^{1}$, Dr. G. Shankar ${ }^{2}$, Dr. S Ramakoteshwara Rao ${ }^{3}$ \\ ${ }^{1}$ Dr. K. Srinivas, Assistant Professor and Addl. Controller of Examinations, Department of Commerce, Osmania University-500007. \\ ${ }^{2}$ Dr. G. Shankar, Research Scholar and Sr. Lecturer in Govt. Degree College, Dept of commerce, Osmania University, Hyderabad, Telangana. \\ ${ }^{3}$ Dr. S Ramakoteshwara Rao, Principal and Professor, Department of Commerce and Business Management, Dhanvantari Institute of Management \\ Sciences, Kothagudem \\ DOI: 10.29322/IJSRP.10.06.2020.p10297 \\ http://dx.doi.org/10.29322/IJSRP.10.06.2020.p10297
}

\begin{abstract}
SHGs play a societal role in the life of women in the group of people with the motive to empower them. Once they realize the significance of savings in their lives they start income creation activities to support their families. SHGs give the women a stand to express themselves. They enhance people's involvement for public accountability and community empowerment through organization of community participation process and ensuring democratic representation of people for sustainable development of communities.

In the present paper an attempt has been made to evaluate community participation in Manakondur and Karimnagar Constituency after Joining SHGs. Further, an attempt has also been made to measure the community participation, community interaction organizations interaction participate in cultural activities and festivals, participate in programmes and protest against denied opportunities help to government officials of sample respondents is also examined. The analysis is mainly based on the primary data collected from the sample consumers through field study and used " $t$ test" also. We conclude that their interaction with the community has been improved more in Karimanagar constituency when compared to Manakondur Constituency after joining self help groups. Government should promote microfinance systems only when the beneficiaries link their activities to social mobilization and community empowerment. Politicall interference seems to be a block for effective functioning of SHGs in both the constituencies. Moreover the officals should stop discriminative attitude. The NGOs and other officials should be trained for effective monitoring of SHGs.
\end{abstract}

Index Terms- SHGs, Microfinance, Non-Banking Financial Companies (NBFCs), Commercial Banks, Regional Rural Banks (RRBs)

\section{INTRODUCTION}

$\mathrm{S}^{\mathrm{H}}$ HGs play a social role in the lives of women in the community with the motive to empower them. Once they realize the importance of savings in their lives they start income generation activities to support their families. SHGs give the women a platform to express themselves. They enhance people's participation for public accountability and community empowerment through organization of community participation process and ensuring democratic representation of people for sustainable development of communities.

Microfinance segment has become quickly in the course of recent decades. Nobel Laureate Muhammad Yunus is credited with establishing the framework of the cutting edge MFIs with foundation of Grameen Bank, Bangladesh in 1976. Today it has developed into a lively industry showing an assortment of plans of action. Microfinance Institutions (MFIs) in India exist as "NGO"s (enlisted as social orders or trusts), Non-Banking Financial Companies (NBFCs), Commercial Banks, Regional Rural Banks (RRBs), helpful social orders and other huge money lenders. These players have assumed a significant role in giving renegotiate office to MFIs. Banks have additionally utilized the Self-Help Group (SHGs) channel to give direct credit to assemble borrowers.

\section{OBJeCtIVES OF THE STUDY:}

The specific objectives of the present study are:

1. To study community participation in after Joining SHGs.

2. To compare the community participation in Manakondur and Karimnagar Constituency after Joining SHGs.

3. To suggest appropriate suggestions for improving the community participation.

\section{Methodology:}

Primary data: The primary data was collected by administering a structured questionnaire to the primary members of SHGs functioning in reserved Manakondur constituency and Karimnagar an unreserved constituency in erstwhile Karimnagar

Secondary data: The secondary data was collected and compiled from internal records and reports of SHGs and DRDA, Journals like Economic and Political Weekly, Indian Journal of Commerce, SHADHAN and documents published by other regulating bodies etc.

Karimnagar is one of the districts which exhibit the poverty of the State. Manakondur constituency, reserved constituency for 
SC and Karimnagar constituency, an unreserved constituency in erstwhile Karimnagar of Telangana State was chosen for the present study. A sample of 200 member beneficiaries from Manakondur constituency, a reserved constituency for SC and 200 members from Karimnagar constituency, an unreserved constituency were selected as respondents for the purpose of this study. The sample was selected based on Multi stage sampling method. In the next stage two Revenue Mandals were selected ad from each revenue mandal 5 villages were chosen. From each village two SHG's and from each SHG, approximately twenty beneficiaries or members of SHG's have been considered as respondents.

\section{Hypothesis:}

Ho $=$ There is no significant difference between Respondents Community Participation in Manakondur and Karimnagar Constituency after Joining SHGs.

$\mathrm{Ha}=$ There is a significant difference between Respondents Community Participation in Manakondur and Karimnagar Constituency after Joining SHGs.

\section{Comparative Analysis of Community participation in Manakondur and Karimnagar:}

Human being is a social animal and every person is expected to participate in community activities. The respondents are expected to interact with community, organizations, cultural activities, helping the government officials and so on. Hence the respondents were asked to reveal their opinion about various factors of community participation activities on a five point scale. The most preferred one should be rated as strongly agree and last preference by strongly disagree. The response to the first factor i.e. interaction with the community is placed in Table 1.

\section{COMMUNITY INTERACTION:}

From Table 1, regarding interaction with the community after joining self help groups by the respondents in Manakondur constituency, it is observed that 42.70 per cent neither agree nor disagree with the statement and 38.20 per cent agree and 19.10 per cent strongly agree with the statement that they interaction with the community. The mean score of the sample respondents after joining the self help groups in Manakondur stood at 44.67 about interaction with the community. Whereas the data relating to the interaction with the community after joining self help groups by the respondents in Karimnagar constituency reveals that, 69.89 per cent agree and 13.64 per cent of respondents strongly agree with the statement of interaction with the community. The mean score of the sample respondents after joining the self help groups in Karimnagar stood at 3.72. This shows that their interaction with the community has been improved more in Karimanagar constituency when compared to Manakondur Constituency after joining self help groups.

It is observed from the result of ' $\mathrm{t}$ ' test that the calculated value (1.578) is less than the Critical value (2.132) at degrees of freedom $V=4$ at 5 per cent level of significance, , and $\mathrm{P}$ value .116. Hence null hypothesis of no significant difference between interaction with the community after joining the self help groups among Manakondur and Karimnagar respondents has been accepted and concluded that there is no significant difference in interaction with the community among Manakondur and Karimnagar respondents after joining self help groups.

Non-Banking Financial Companies (NBFCs), Commercial Banks, Regional Rural Banks (RRBs),From Table it is observed that 43.82 per cent agree with the statement and 16.85 per cent strongly agree with the statement that they interact with the organizations after joining self help groups by the respondents in Manakondur constituency. The mean score of the sample respondents after joining the self help groups in Manakondur stood at 44.40 about interact with the organizations. Whereas the data relating to the interact with the organizations after joining self help groups by the respondents in Karimnagar constituency reveals that, 52.27 per cent agree and 31.82 per cent of respondents neither agree nor disagree with the statement of interact with the organizations. The mean score of the sample respondents after joining the self help groups in Karimnagar stood at 3.93. This shows that the interaction with the organizations has been improved more in Karimanagar Constituency after joining self help groups.

It is observed from the result of ' $\mathrm{t}$ ' test that the calculated value (4.232) is greater than the Critical value (2.132) at degrees of freedom $V=4$ at 5 per cent level of significance, , and $\mathrm{P}$ value .000 . Hence null hypothesis of no significant difference between interact with the organizations after joining the self help groups among Manakondur and Karimnagar respondents has been rejected and concluded that there is significant difference in interact with the organizations among Manakondur and Karimnagar respondents after joining self help groups.

\section{PARTICIPATE IN CULTURAL ACTIVITIES AND FESTIVALS:}

Table reveals that 39.33 per cent agree with the statement and 14.61 per cent strongly agree with the statement that they participate in cultural activities and festivals after joining self help groups by the respondents in Manakondur constituency. The mean score of the sample respondents after joining the self help groups in Manakondur stood at 41.87 about participate in cultural activities and festivals. Whereas the data participate in cultural activities and festivals after joining self help groups by the respondents in Karimnagar constituency reveals that, 48.86 per cent agree and 20.45 per cent of respondents strongly agree with the statement of participate in cultural activities and festivals. The mean score of the sample respondents after joining the self help groups in Karimnagar stood at 3.85. This shows that their participation in cultural activities and festivals has been improved more in Karimanagar Constituency after joining self help groups. It is observed from the result of ' $t$ ' test that the calculated value (3.531) is greater than the Critical value (2.132) at degrees of freedom $V=4$ at 5 per cent level of significance, hence, and $\mathrm{P}$ value .000 . Hence null hypothesis of no significant difference between participate in cultural activities and festivals after joining the self help groups among Manakondur and Karimnagar respondents has been rejected and concluded that there is significant difference in participate in cultural activities and festivals among Manakondur and Karimnagar respondents after joining self help groups. 


\section{PARTICIPATE IN PROGRAMMES:}

Table depicts that 33.71 per cent agree with the statement, 15.73 per cent strongly agree and 46.07 per cent neither agree nor disagree with the statement that they participate in programmes after joining self help groups by the respondents in Manakondur constituency. The mean score of the sample respondents after joining the self help groups in Manakondur stood at 42.80 about participate in programmes. Whereas the data relating to the participate in programmes after joining self help groups by the respondents in Karimnagar constituency reveals that, 68.18 per cent agree and 23.86 per cent of respondents neither agree nor disagree with the statement of participate in programmes. The mean score of the sample respondents after joining the self help groups in Karimnagar stood at 3.72. This shows that their participation in programmes has been improved more in Karimanagar Constituency after joining self help groups.

It is observed from the result of ' $t$ ' test that the calculated value (1.562) is less than the Critical value (2.132) at degrees of freedom $V=4$ at 5 per cent level of significance,, and $\mathrm{P}$ value .119. Hence null hypothesis of no significant difference between participation in programmes after joining the self help groups among Manakondur and Karimnagar respondents has been accepted and concluded that there is no significant difference in participation in programmes among Manakondur and Karimnagar respondents after joining self help groups.

\section{PROTEST AGAINST DENIED OPPORTUNITIES:}

From Table it can be said after joining self help groups by the respondents in Manakondur constituency, it was found that 43.82 per cent agree with the statement and 20.22 per cent strongly agree with the statement that they protest against denied opportunities. The mean score of the sample respondents after joining the self help groups in Manakondur stood at 45.20 about protest against denied opportunities. Whereas the data relating to the protest against denied opportunities after joining Self help groups by the respondents in Karimnagar constituency reveals that, 55.11 per cent agree and 26.14 per cent of respondents neither agree nor disagree with the statement of protest against denied opportunities. The mean score of the sample respondents after joining the self help groups in Karimnagar stood at 3.81. This shows that their protest against denied opportunities has been improved more in Manakondur constituency when compared to Karimanagar Constituency after joining self help groups.

It is observed from the result of ' $t$ ' test that the calculated value (0.043) is less than the Critical value (2.132) at degrees of freedom $V=4$ at 5 per cent level of significance, , and $\mathrm{P}$ value .966 . Hence null hypothesis of no significant difference between protest against denied opportunities after joining the self help groups among Manakondur and Karimnagar respondents has been accepted and concluded that there is no significant difference in protest against denied opportunities among Manakondur and Karimnagar respondents after joining self help groups.

\section{HELP TO GOVERNMENT OFFICIALS:}

From Table 1 it can be observed that after joining self help groups by the respondents in Manakondur constituency, it was found that 32.58 per cent agree with the statement, 12.36 per cent strongly agree and 51.69 per cent of the respondents neither agree nor disagree with the statement that they help government officials. The mean score of the sample respondents after joining the self help groups in Manakondur stood at 42.00 about help government officials. Whereas the data relating to the help government officials after joining Self help groups by the respondents in Karimnagar constituency reveals that, 49.43 per cent agree and 23.30 per cent strongly agree and 25.00 per cent of respondents neither agree nor disagree with the statement of help government officials. The mean score of the sample respondents after joining the self help groups in Karimnagar stood at 3.92. This shows that their help government officials have been improved more in Karimanagar constituency when compared to Manakondur constituency after joining self help groups.

It is observed from the result of ' $\mathrm{t}$ ' test that the calculated value (4.708) is greater than the Critical value (2.132) at degrees of freedom $V=4$ at 5 per cent level of significance, , and $\mathrm{P}$ value .000 . Hence null hypothesis of no significant difference between help government officials after joining the self help groups among Manakondur and Karimnagar respondents has been rejected and concluded that there is significant difference in help government officials among Manakondur and Karimnagar respondents after joining self help groups.

\section{CONCLUSION AND SugGestions:}

The analysis clearly found that there is a significant difference between Karimanagar constituency and Manakondur Constituency with reference to Community Interaction, Participate in cultural activities, festivals and Help to Government Officials. Hence we accept the alternate hypothesis. On the other variables like Community Interaction, Participate in Programmes and Protest against denied opportunities are no difference between the Karimanagar constituency when compared to Manakondur Constituency after joining self help groups. Hence accept the null hypothesis. We conclude that their interaction with the community has been improved more in Karimanagar constituency when compared to Manakondur Constituency after joining self help groups. Government should promote microfinance systems only when the beneficiaries link their activities to social mobilization and community empowerment. Politicall interference seems to be a block for effective functioning of SHGs in both the constituencies. Moreover the officals should stop discriminative attitude. The NGOs and other officials should be trained for effective monitoring of SHGs.

\section{REFERENCES}

[1] Goyal and Goel(2012) Microfinance in India-An evaluation of Self Help Groups Scheme. paper presented in the Third European Research Conference on Microfinance, University of Agder, Kristiansand, Norway.

[2] Mohan. K. (2011) "Role of Micro Finance in Women's Empowerment", Journal of Management and Science, Vol. 1, No.1, Sep 2011, pp. 1-10 ISSN: 2249-1260.

[3] Reddy and Malik (2011) Microfinance Industry in India: Some Thoughts october 8, 2011 vol xlvi no 41 EPW Economic \& Political Weekly.

[4] Prabhakar (2011) Economic Development of Women through Self Help Groups in YSR District, Andhra Pradesh, India Stud Home Com Sci, 7(1): 25-34 (2013). 
[5] Kumar (2010) Microfinance and Mobile Banking: The Story So Far Focus Note 62. Washington, D.C.: CGAP.

[6] Karmakar, (2010) "microfinance" in Responsible Marketing for Sustainable Business, zenon academic publishing, 31-mar-2016 - business \& economics - 206 pages.

[7] Prabhakar (2010) ), Economic Development of Women through Self Help Groups in YSR District, Andhra Pradesh, India Stud Home Com Sci, 7(1): 25-34 (2013).

[8] Wallenstein (2009) The impact of microfinance on factors empowering women: Regional and Delivery Mechanisms in India's SHG Programme stanford center for international development, jan,2014.

[9] Browning and Chiappori, (1998); Duflo, (2003) Browning, Martin, and Pierre-Andre Chiappori (1998) 'Efficient intra-household allocations: A general characterization and empirical tests.'Econometrica 66(6), 12411278.

[10] Puhazhendhi et al(2002): SHG-Bank Linkage Programme for Rural Poor in India: An Impact Assessment. Microcredit Innovations Department, National Bank for Agriculture and Rural Development, Mumbai.

\section{AUTHORS}

First Author - Dr. K. Srinivas, Assistant Professor and Addl.

Controller of Examinations, Department of Commerce, Osmania University-500007. kamatamsrinivas@gmail.com.

Second Author - Dr. G. Shankar, Research Scholar and Sr. Lecturer in Govt. Degree College, Dept of commerce, Osmania University, Hyderabad, Telangana.

Third Author - Dr. S Ramakoteshwara Rao, Principal and Professor, Department of Commerce and Business Management, Dhanvantari Institute of Management Sciences, Kothagudem, sadanalark@gmail.com

\section{ANNEXURE:}

\section{Community Participation of the Respondents of Manakondur and Karimnagar Constituency after joining Self help groups}

\begin{tabular}{|c|c|c|c|c|c|c|c|c|c|c|c|c|c|c|c|}
\hline \multirow[b]{2}{*}{$\begin{array}{l}\mathrm{Sl} \\
\mathrm{N} \\
\mathrm{O}\end{array}$} & \multirow[b]{2}{*}{ Item } & \multicolumn{6}{|c|}{ Manakondur Constituency } & \multicolumn{6}{|c|}{ Karimnagar Constituency } & \multirow[b]{2}{*}{$\begin{array}{l}\mathrm{T}- \\
\text { test }\end{array}$} & \multirow[b]{2}{*}{$\begin{array}{l}\text { P } \\
\text { Val } \\
\text { ue }\end{array}$} \\
\hline & & 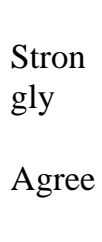 & $\begin{array}{l}\text { Agre } \\
\mathrm{e}\end{array}$ & $\begin{array}{l}\text { Neith } \\
\text { er } \\
\text { Agree } \\
\text { Nor } \\
\text { Disag } \\
\text { ree }\end{array}$ & $\begin{array}{l}\text { Disag } \\
\text { ree }\end{array}$ & $\begin{array}{l}\text { Stron } \\
\text { gly } \\
\text { Disag } \\
\text { ree }\end{array}$ & $\begin{array}{l}\text { Me } \\
\text { an } \\
\text { Sco } \\
\text { re }\end{array}$ & $\begin{array}{l}\begin{array}{l}\text { Stron } \\
\text { gly }\end{array} \\
\text { Agree }\end{array}$ & $\begin{array}{l}\text { Agre } \\
\mathrm{e}\end{array}$ & $\begin{array}{l}\text { Neith } \\
\text { er } \\
\text { Agree } \\
\text { Nor } \\
\text { Disag } \\
\text { ree }\end{array}$ & $\begin{array}{l}\text { Disag } \\
\text { ree }\end{array}$ & $\begin{array}{l}\text { Stron } \\
\text { gly } \\
\text { Disag } \\
\text { ree }\end{array}$ & $\begin{array}{l}\text { Me } \\
\text { an } \\
\text { Sco } \\
\text { re }\end{array}$ & & \\
\hline 1 & $\begin{array}{l}\text { Communi } \\
\text { ty } \\
\text { Interactio } \\
\mathrm{n}\end{array}$ & $\begin{array}{l}34 \\
(19.1 \\
0)\end{array}$ & $\begin{array}{l}68 \\
(38.2 \\
0)\end{array}$ & $\begin{array}{l}76 \\
(42.70 \\
)\end{array}$ & $\begin{array}{l}0 \\
0\end{array}$ & $\begin{array}{l}0 \\
0\end{array}$ & $\begin{array}{l}3.7 \\
6\end{array}$ & $\begin{array}{l}24 \\
(13.6 \\
4)\end{array}$ & $\begin{array}{l}123 \\
(69.8 \\
9)\end{array}$ & $\begin{array}{l}21 \\
(11.93 \\
)\end{array}$ & $\begin{array}{l}2 \\
(1.14)\end{array}$ & $\begin{array}{l}6 \\
(3.4)\end{array}$ & $\begin{array}{l}3.7 \\
2\end{array}$ & $\begin{array}{l}1.5 \\
78\end{array}$ & $\begin{array}{l}0.11 \\
6\end{array}$ \\
\hline 2 & $\begin{array}{l}\text { Organizat } \\
\text { ions } \\
\text { Interactio } \\
\mathrm{n}\end{array}$ & $\begin{array}{l}30 \\
(16.8 \\
5)\end{array}$ & $\begin{array}{l}78 \\
(43.8 \\
2)\end{array}$ & $\begin{array}{l}64 \\
(35.96 \\
)\end{array}$ & $\begin{array}{l}6 \\
(3.47)\end{array}$ & $\begin{array}{l}0 \\
0\end{array}$ & $\begin{array}{l}3.7 \\
4\end{array}$ & $\begin{array}{l}56 \\
(31.8 \\
2)\end{array}$ & $\begin{array}{l}92 \\
(52.2 \\
7)\end{array}$ & $\begin{array}{l}22 \\
(12.50 \\
)\end{array}$ & $\begin{array}{l}2 \\
(1.14)\end{array}$ & $\begin{array}{l}4 \\
(2.27)\end{array}$ & $\begin{array}{l}3.9 \\
3\end{array}$ & $\begin{array}{l}4.2 \\
32\end{array}$ & $\begin{array}{l}0.00 \\
0\end{array}$ \\
\hline 3 & $\begin{array}{l}\text { participat } \\
\mathrm{e} \text { in } \\
\text { Cultural } \\
\text { activities } \\
\text { and } \\
\text { Festivals }\end{array}$ & $\begin{array}{l}26 \\
(14.6 \\
1)\end{array}$ & $\begin{array}{l}70 \\
(39.3 \\
3)\end{array}$ & $\begin{array}{l}54 \\
(30.34 \\
)\end{array}$ & $\begin{array}{l}28 \\
(15.73 \\
)\end{array}$ & $\begin{array}{l}0 \\
0\end{array}$ & $\begin{array}{l}3.5 \\
2\end{array}$ & $\begin{array}{l}36 \\
(20.4 \\
5)\end{array}$ & $\begin{array}{l}86 \\
(48.8 \\
6)\end{array}$ & $\begin{array}{l}46 \\
(26.14 \\
)\end{array}$ & $\begin{array}{l}8 \\
(4.55)\end{array}$ & $\begin{array}{l}0 \\
0\end{array}$ & $\begin{array}{l}3.8 \\
5\end{array}$ & $\begin{array}{l}3.5 \\
31\end{array}$ & $\begin{array}{l}0.00 \\
0\end{array}$ \\
\hline 4 & $\begin{array}{l}\text { participat } \\
\text { e in } \\
\text { program } \\
\text { mes }\end{array}$ & $\begin{array}{l}28 \\
(15.7 \\
3)\end{array}$ & $\begin{array}{l}60 \\
(33.7 \\
1)\end{array}$ & $\begin{array}{l}82 \\
(46.07 \\
)\end{array}$ & $\begin{array}{l}8 \\
(4.49)\end{array}$ & $\begin{array}{l}0 \\
0\end{array}$ & $\begin{array}{l}3.6 \\
0\end{array}$ & $\begin{array}{l}8 \\
(4.55)\end{array}$ & $\begin{array}{l}120 \\
(68.1 \\
8)\end{array}$ & $\begin{array}{l}42 \\
(23.86 \\
)\end{array}$ & $\begin{array}{l}4 \\
(2.27)\end{array}$ & $\begin{array}{l}2 \\
(1.14)\end{array}$ & $\begin{array}{l}3.7 \\
2\end{array}$ & $\begin{array}{l}1.5 \\
62\end{array}$ & $\begin{array}{l}0.11 \\
9\end{array}$ \\
\hline 5 & $\begin{array}{l}\text { protest } \\
\text { against } \\
\text { denied }\end{array}$ & $\begin{array}{l}36 \\
(20.2 \\
2)\end{array}$ & $\begin{array}{l}78 \\
(43.8 \\
2)\end{array}$ & $\begin{array}{l}58 \\
(32.58 \\
)\end{array}$ & $\begin{array}{l}6 \\
(3.37)\end{array}$ & $\begin{array}{l}0 \\
0\end{array}$ & $\begin{array}{l}3.8 \\
0\end{array}$ & $\begin{array}{l}27 \\
(15.3 \\
4)\end{array}$ & $\begin{array}{l}97 \\
(55.1 \\
1)\end{array}$ & $\begin{array}{l}46 \\
(26.14 \\
)\end{array}$ & $\begin{array}{l}4 \\
(2.27)\end{array}$ & $\begin{array}{l}2 \\
(1.14)\end{array}$ & $\begin{array}{l}3.8 \\
1\end{array}$ & $\begin{array}{l}.04 \\
3\end{array}$ & $\begin{array}{l}0.96 \\
6\end{array}$ \\
\hline
\end{tabular}


International Journal of Scientific and Research Publications, Volume 7, Issue 8, August 2017

829 ISSN 2250-3153

\begin{tabular}{|c|c|c|c|c|c|c|c|c|c|c|c|c|c|c|c|}
\hline & $\begin{array}{l}\text { opportuni } \\
\text { ties }\end{array}$ & & & & & & & & & & & & & & \\
\hline 6 & $\begin{array}{l}\text { Help to } \\
\text { Governm } \\
\text { ent } \\
\text { Officials }\end{array}$ & $\begin{array}{l}22 \\
(12.3 \\
6)\end{array}$ & $\begin{array}{l}58 \\
(32.5 \\
8)\end{array}$ & $\begin{array}{l}92 \\
(51.69 \\
)\end{array}$ & $\begin{array}{l}6 \\
(3.37)\end{array}$ & 0 & $\begin{array}{l}3.5 \\
3\end{array}$ & $\begin{array}{l}41 \\
(23.3 \\
0)\end{array}$ & $\begin{array}{l}87 \\
(49.4 \\
3)\end{array}$ & $\begin{array}{l}44 \\
(25.00\end{array}$ & $\begin{array}{l}2 \\
(1.14)\end{array}$ & $\begin{array}{l}2 \\
(1.14)\end{array}$ & $\begin{array}{l}3.9 \\
2\end{array}$ & $\begin{array}{l}4.7 \\
08\end{array}$ & $\begin{array}{l}0.00 \\
0\end{array}$ \\
\hline
\end{tabular}

Source: Primary data 